\title{
REFORMING AFRICAN ABORTION LAWS TO ACHIEVE TRANSPARENCY: ARGUMENTS FROM EQUALITY
}

\author{
CHARLES G. NGWENA *
}

\section{INTRODUCTION}

The historical criminalisation of abortion is a major explanation for the persistence of unsafe abortion in the African region. As long as criminalisation remains the main tool for regulating abortion, the question of reforming African abortion laws will not go away. The African region carries a disproportionate burden of unsafe abortion at a time when technologies and procedures for terminating pregnancy have become not only much easier to use and safer, but also more affordable. In the Global South, where doctors are highly scarce and/or their distribution is highly skewed, appropriately trained mid-level providers can, if domestic law permits, be trained to safely perform abortions using methods such as MVA (manual vacuum aspiration). ${ }^{1}$ In this regard, South Africa has led the way in the African region by recognising the competence of appropriately trained midwives and nurses to perform abortions in the first trimester, ${ }^{2}$ with a salutary effect on substantially broadening access to safe abortion. ${ }^{3}$ Another important development is the advent of medical abortion. Medicines for procuring abortion obviate the need for invasive surgery, making it even more feasible for developing countries to meet abortion needs, without first incurring large capital outlays in health infrastructure and human resources. ${ }^{4}$ Thus, given political willingness, it is not

* LLB, LLM (Wales), LLD (Free State), Professor, Centre for Human Rights, University of Pretoria, South Africa. Email: charlesngwena@gmail.com.

1 D. A. Grimes, J. Benson, S. Singh, M. Romero, B. Ganatra, F. E. Okonofua and I. H. Shah, 'Unsafe Abortion: the Preventable Pandemic', 368 Lancet (2006): 1,908-19, at 1,915; J. Yarnall, Y. Swica and B. Winikoff, 'Non-physician Clinicians Can Safely Provide First Trimester Medical Abortion', 17 Reproductive Health Matters (2009): 61-9.

2 Choice on Termination of Pregnancy Act 1996 section 2(2) as amended by the Choice on Termination of Pregnancy Act 2004 section 1.

3 C. Ngwena, 'The History and Transformation of Abortion Law in South Africa', 30 Acta Academica (1998): 32-68, at 47-8, 66; K. Dickson-Tetteh and D. L. Billings, 'Abortion Care Services Provided by Registered Midwives in South Africa', 28 International Family Planning Perspectives (2002): 144-50.

4 I. K. Warriner, Unsafe Abortion: An Overview of Priorities and Needs, in I. K. Warriner and I. H. Shah (eds), Preventing Unsafe Abortion and Its Consequences, Guttmacher (2006), pp. 1-14, at 
cost that largely stands in the way of the African region meeting abortion needs, but the historical criminalisation of abortion.

In essence, this article argues that where abortion is permitted under domestic law, even in a very restricted form, the State has a corresponding duty to ensure that any attendant rights are amenable to effective realisation. This entails, inter alia, a duty to raise awareness about the legality of abortion among women and healthcare providers. Furthermore, it entails taking steps to ensure that women seeking abortion have access to administrative procedures that facilitate timely review of any decisions to refuse abortion so that litigation, which promises, at best, a retrospective vindication of legal rights for women, becomes an option of last rather than first resort for women who do not wish to become mothers in the first place. These state duties can be described as 'transparency' duties. ${ }^{5}$

The rationale for arguing for transparency is that laws that criminalise abortion but without concomitantly articulating clearly the grounds for lawful abortion, as has been the main historical trend in the African region, unduly deter healthcare providers from providing health services to women even where abortion is lawful. Equally, such laws create misperceptions about abortion as conduct that is criminal at all times. The general failure by the legislative and executive arms of government in the African region to translate any given abortion rights into rights that are visible and tangible has served as a veritable barrier to safe abortion services.

Ultimately, this article seeks to develop a normative theoretical framework for transparency using transformative notions of equality. It is argued that transparency is, in part, a way of situating abortion law in procedural equality. Transparency serves the value of achieving equal protection under the law. ${ }^{6}$ Even where the public shares different views about abortion, as is guaranteed, taking a philosophical cue from the work of John Rawls, it is argued that it is possible to see transparency as an expression of an 'overlapping consensus' on the need for effective implementation of legal rights in a liberal democracy that is committed to equal opportunities. ${ }^{7}$ The overlapping consensus is ultimately underpinned by a conception of political liberalism among people who have different and even incommensurable comprehensive religious, philosophical or moral conceptions of a good life, but can, nonetheless, agree that according citizens equal opportunities to exercise their rights under the law is an important value of justice as fairness. Such consensus is integral to organising the basic structure of society, including its legal institutions. ${ }^{8}$

pp. 1, 4-5; S. Clarke et al., 'Misoprostol Use in Obstetrics and Gynecology in Brazil, Jamaica, and the United States', 76 International Journal of Gynecology and Obstetrics (2002): 65-74.

5 R. J. Cook, J. Erdman and B. Dickens, 'Achieving Transparency in Implementing Abortion Laws', 99 International Journal of Gynecology \& Obstetrics (2007): 157-61; C. G. Ngwena, 'Inscribing Abortion as a Human Right: Significance of the Protocol on the Rights of Women', 32 Human Rights Quarterly (2010): 783-864, at 806-8.

6 R. J. Cook and S. Howard, 'Accommodating Women's Differences under the Women's AntiDiscrimination Convention', 56 Emory Law Journal (2007): 1,039-91, at 1,067-9.

7 J. Rawls, Political Liberalism, Columbia University Press (2005), pp. 131-72.

8 Ibid. 
This article also argues that transparency is a way of situating abortion law in substantive equality by grounding abortion law in actual lives lived and injuries suffered by women. Substantive equality seeks to ensure that abortion law is woman-centred and adequately responsive to the needs of a social group whose reproductive needs have historically been criminalised and stigmatised by society and health systems. In this sense, the duty of transparency becomes a transformative way of thinking about human rights not just as claims that impose duties of restraint on the State, but also as claims that impose positive obligations aimed at enabling the effective realisation of rights. ${ }^{9}$ The arguments from substantive equality principally draw from Nancy Fraser's critical theory of recognition, ${ }^{10}$ and the capabilities approach of Amartya Sen ${ }^{11}$ and Martha Nussbaum. ${ }^{12}$

The article has five sections. Section I, the present section, is the introduction. Section II summarises the historical development of African abortion laws. It draws a link between the criminalisation of abortion and unsafe abortion, and highlights lack of transparency as a contributory factor. Section III posits transparency as an expression of Rawls' idea overlapping consensus and an integral part of any human rights application of abortion rights irrespective of moral views about abortion. Section III also draws from recent global and regional abortion-related jurisprudential developments on transparency. Section IV advances a transformative normative rationale for transparency arguing from the capabilities approach. Section V is the conclusion.

\section{HISTORICAL DEVELOPMENT OF AFRICAN ABORTION LAWS AND THE LINK WITH UNSAFE ABORTION}

\section{A. Persistence of a crime and punishment model}

The origins of African abortion laws lie largely in colonial jurisprudence. Abortion laws were transplanted from Europe to Africa interimbricated with masculinist theologies that emanated from deeply entrenched patriarchal power. Criminalisation of abortion in the colonising European countries sought to protect sanctity of foetal life and reflect abortion as religious $\sin .{ }^{13}$ The underpinning

9 S. Fredman, Human Rights Transformed: Positive Rights and Positive Duties, Oxford University Press (2006), pp. 10-14.

10 N. Fraser, Iustice Interruptus, Routledge (1997); N. Fraser, 'Rethinking Recognition', 3 New Left Review (2000): 107-20; N. Fraser and A. Honneth, Redistribution or Recognition? A Political-Philosophical Exchange, Verso (2003).

11 A. Sen, Development as Freedom, Anchor Books (1999), pp. 74-110; A. Sen, 'Elements of a Theory of Human Rights', 32 Philosophy \& Public Affairs (2005): 315-56, at 328-38; A. Sen, 'Gender Inequality and Theories of Justice', in M. C. Nussbaum and J. Glover (eds), Women, Culture and Development, Oxford University Press (2007), pp. 259-73.

12 M. C. Nussbaum, Women and Human Development: The Capabilities Approach, Cambridge University Press (2000); M. C. Nussbaum, 'Human Capabilities, Female Human Beings', in Nussbaum and Glover (eds), Women, Culture and Development, ibid., pp. 62-104.

13 R. J. Cook and B. M. Dickens, 'Human Rights Dynamics of Abortion Law Reform', 25 Human Rights Quarterly (2003): 1-59, at 8-9. 
philosophies were shaped primarily by Catholic theologies, but also Protestant theologies after the Protestant Reformation of the $16^{\text {th }}$ century. ${ }^{14}$ As with JudaeoChristian theories and praxis of the time, the theologies were not inclusive. They did not concern themselves with accommodating the life and experience of women as persons whose well-being and life plans must be respected because of their intrinsic value. ${ }^{15}$ Rather, they were androcentric, drawing impulse from an enduring archive of patriarchy in which patterns of subordinating women were legitimised and naturalised by the Christian Church. ${ }^{16}$ The theologies spoke more to a gendered political economy that could only imagine equality as 'equality in distinction' where women are differentiated physiological beings with a scripted sex role in which maternity is a principal vocation, than to an inclusive society in which women are valued as much as men, or there is mutual affirmation and reciprocity between sexes. ${ }^{17}$ Women's agency and the adverse socio-economic circumstances in which many women struggle to control their fertility, were matters that scarcely exercised the underpinning theologies.

As elsewhere, colonial abortion laws in Africa mirrored the laws of the colonising countries in prescribing abortion as a crime, save when it was procured to save the life of the pregnant woman. This exception, which became known as the 'therapeutic exception', was expressed or implied in legislation or unwritten law. According to Reva Siegel, the historical development of the therapeutic exception captures poignantly the scripted role of women as reproductive instruments and physiological beings. ${ }^{18}$ It is a role that had more to do with the imperatives of the singular structural power of patriarchy than with the ostensible claim of reverence towards foetal life. As a defence to the criminalisation of abortion, women could only be permitted to procure abortion if medically the pregnancy brought them perilously close to losing their lives. ${ }^{19}$ No comparable sacrifice has ever been legally required of males in terms of their procreative capacities.

14 R. J. Cook and B. M. Dickens, 'The Injustice of Unsafe Motherhood', 2 Developing World Bioethics (2002): 64 81, at 73.

15 E. Vuola, 'Thinking Otherwise: Dussel, Liberation Theology and Feminism', in L. M. Alcoff and E. Mendieta (eds), Thinking from the Underside: Enrique Dussel's Philosophy of Liberation, Rowman and Littlefield (2000), pp. 149-80, p. 166; B. W. Harrison, Our Right to Choose: Towards an Ethic of Abortion, Beacon (1983), pp. 6, 16.

16 D. M. Ackermann, 'Being Woman, Being Human', in D. M. Ackermann, J. A. Draper and E. Mashinini (eds), Women Hold Up Half the Sky: Women in the Church in Southern Africa, Cluster Publications (1991), pp. 93-105, at pp. 95-100; D. M. Ackermann, "For Such a Thing is not Done in Israel": Violence Against Women', in L. Hulley, L. Kretzschmar and L. L. Pato (eds), Archbishop Tutu: Prophetic Witness in South Africa, David Philip (1996), pp. 145-55, at p. 150.

17 Vuola, 'Thinking Otherwise', supra note 15, p. 155.

18 R. Siegel, 'Reasoning from the Body: A Historical Perspective on Abortion Regulation and Questions of Equal Protection', 44 Stanford Law Review (1992): 261-381; Cook and Howard, 'Accommodating Women's Differences', supra note 6, at 1,048-51.

19 Siegel, ibid., at 365; Cook and Howard, ibid., at 1,048-51. 
In former British colonies, abortion law was primarily shaped by the English Offences Against the Person Act 1861 and supplemented by common law. ${ }^{20}$ Similarly, in the former colonies of Belgium, France, Italy, Portugal, and Spain, colonial penal codes faithfully reflected the laws of the colonising countries with the French Penal Code 1810 as the abiding influence. ${ }^{21}$ But while the former imperial powers have since substantially liberalised their laws, independent African countries have been very slow to reform abortion laws in ways that make a difference to women. In several African countries, abortion laws have seemingly stood still, with saving the life of the pregnant woman understood as the only ground of abortion. ${ }^{22}$ Furthermore, abortion laws have rarely been operationalised to enable women as well as healthcare providers to sufficiently know when abortion is lawful. Malawi's abortion law serves a case in point.

Malawi became a British colony in 1891 and attained independence in 1964. Its abortion law, as contained in the Malawian Penal Code, is a colonial legacy. Abortion is a serious offence that carries a maximum punishment of 14 years in prison. The main governing provision is section 149 of the Penal Code which says:

Any person who, with intent to procure a miscarriage of a woman, whether she is or not with child, unlawfully administers to her or causes her to take any poison or other noxious thing, or uses any force of any kind, or uses any other means whatsoever, shall be guilty of a felony and shall be liable to imprisonment for fourteen years.

The main defence to a charge of unlawfully procuring an abortion is contained in section 243 of the Penal Code which says:

A person is not criminally responsible for performing in good faith and with reasonable care and skill a surgical operation upon any person for his benefit, or upon an unborn child for the preservation of the mother's life, if the performance of the operation is reasonable, having regard to the patient's state at the time, and to all the circumstances of the case.

The colonial provenance of section 149 of the Malawian Penal Code is section 58 of the English Offences Against the Person Act 1861. Part of the problem with how abortion law is formulated in section 149, as the Court of Appeal of the United Kingdom analogously found in Family Planning Association of Northern Ireland v Minister of Health, Social Services and Public Safety, ${ }^{23}$ is that, on its

20 R. J. Cook and B. M. Dickens, 'Abortion Laws in African Commonwealth Countries', 25 Journal of African Law (1981) 60; Ngwena, 'Inscribing Abortion as a Human Right', supra note 5, at $830-2$.

21 Ngwena ibid., at 832; B. M. Knoppers, I. Brault and E. Sloss, 'Abortion Law in Francophone Countries', 38 American Journal of Comparative Law (1990): 889-922.

22 Center for Reproductive Rights, 'Worlds Abortion Laws', available at http://reproductiverights. org/en/document/the-worlds-abortion-laws-map-2011 (accessed 5 December 2011).

23 Family Planning Association of Northern Ireland $v$ Minister of Health, Social Services and Public Safety [2004] NICA 39; R. Fletcher, 'Abortion Needs or Abortion Rights? Claiming State Accountability for Women's Reproductive Welfare', 13 Feminist Legal Studies (2005): 123-34. 
own, it does not give clear guidance to women as well as healthcare providers about when abortion is lawful. The Court of Appeal of the United Kingdom held that the state was in breach of its statutory duty to provide health services when it failed to clarify the legality of abortion under the Offences Against the Person Act 1861 of Northern Ireland. Like section 149 of the Malawian Penal Code, the Act of Northern Ireland also derives its provenance from the English Offences Against the Person Act 1861. The court found that, due to lack of guidelines on lawful abortion, women seeking abortion services as well as providers of healthcare services were left quite uncertain about the legality of abortion. Consequently, women were being deterred from accessing domestic services that they were otherwise entitled to. Because of legal uncertainty, thousands of women were travelling to the mainland of the United Kingdom to have abortions at great cost and inconvenience. The court held that the state had a duty to develop and implement guidelines in order to remove the uncertainty. Guidelines to implement abortion law were essential not only to enable women to access services they were entitled to, but also to enable health professionals to provide services that are lawful without fear of prosecution. Furthermore, the guidelines served to clarify the law for health professionals wishing to lawfully exercise the right to conscientious objection. ${ }^{24}$

It might be argued that section 243 of the Malawian Penal Code clarifies the circumstances in which abortion is lawful in that it provides for 'preservation of the mother's life' as a ground for abortion. But unless, there is an attempt to articulate the circumstances in which the defence of preserving the pregnant woman's life is met, women seeking abortion and providers of abortion services are apt to be left uncertain. This is precisely what the European Court of Human Rights held in $A, B$ and $C v$ Ireland.$^{25}$ The case was brought by three applicants who were resident in Ireland. They had travelled to the United Kingdom to have abortions, believing they were not entitled to abortion under Irish abortion law as contained in Article 40.3.3 of the Irish Constitution. One of the applicants, $\mathrm{C}$, argued that Irish abortion law was in breach of Article 8 of the European Convention because it did not contain clear guidelines or procedures that would have enabled her to ascertain whether she met the ground of abortion based on a risk to her life. Whilst upholding the substantive domestic law on abortion as part of giving the state a wide margin of appreciation, ${ }^{26}$ nonetheless, the Court found that Ireland was in breach of Article 8 of the European Convention. This was because Irish law was not accompanied by any guidelines or criteria by which to assess C's risk to life. ${ }^{27}$

24 Family Planning Association of Northern Ireland, ibid., at paras 9, 14.

$25 A, B$ and $C$ v Ireland App. No.25579/05 (2010), [2010] ECHR 2032.

26 In $A, B$ and $C$, for example, the European Court of Human Rights sanctioned, as human rights compliant, domestic law that, in a bid to protect foetal life, only permits abortion where there is a 'real and substantial risk to the life, as distinct from the health, of the mother': $A, B$ and $C$, ibid., at paras 216 42; Attorney General $v X$ and Others [1992] 1 IR1 at para. 37, interpreting Article 40.3.3 of the Irish Constitution which regulates abortion.

$27 A, B$ and $C$, ibid., at para. 253. 
Unsafe abortion constitutes 18 per cent of maternal mortality in Malawi. ${ }^{28}$ Abortion is a significant cause of maternal mortality partly because abortion law is perceived as highly restrictive and is not accompanied by guidelines to enable women or providers to know when abortion is lawful..$^{29}$ The assumption among women, health professionals and the general public is that circumstances in which abortion can be lawful are extremely rare. ${ }^{30}$ For fear of prosecution, providers in the public sector, especially, interpret the law conservatively. ${ }^{31}$ Consequently, though women with adequate financial means and knowledge about the availability of safe, even if 'illegal', services in the private sector avail themselves of safe options, the majority of women have recourse to unsafe abortion. ${ }^{32}$ Even if they have information about the availability of safe abortion services in the private sector, the majority of women are lacking in financial means.

The lack of guidelines on abortion law is not something that one finds only in countries such as Malawi that have retained, virtually wholesale, colonial abortion laws. Though in the last four decades or so, many African countries have been part of a global trend towards reform of highly restrictive abortion laws ${ }^{33}$ in the preponderance of countries, reform has not taken the more liberal route of recognising socio-economic circumstances, or much less, mere request as grounds for abortion. Reforms have, largely, sought to legalise rather than decriminalise abortion by retaining abortion as a crime, but broadening the grounds of abortion beyond saving the life of the pregnant woman, to include rape, the health of the pregnant woman or the life or health of the foetus. With a few exceptions, ${ }^{34}$ there is a distinct lack of operationalising the grounds for abortion. Consequently, the reforms have failed to translate into access to abortion services. For example, though the Zimbabwean Termination of Pregnancy Act $1977^{35}$ recognises, inter alia, risk to the life or physical health of the pregnant woman as grounds for

28 E. Geubbels, 'Epidemiology of Maternal Mortality', 18 Malawi Medical Journal (2006): $206-25$.

29 E. Jackson, B. R. Johnson, H. Gebreselassie, G. D. Kangaude and C. Mhango, 'A Strategic Assessment of Unsafe Abortion in Malawi', 19 Reproductive Health Matters (2011): 133-43.

30 Ibid., at 136.

31 Ibid.

32 Ibid., at $136-7$.

33 E. Brookman-Amissah and J. Banda Moyo, 'Abortion Law Reform in Sub-Saharan Africa: No Turning Back', 12 Reproductive Health Matters (2004): 227; R. Boland and L. Katzive, 'Development on Laws on Induced Abortion: 1998-2007', 34 International Family Planning Perspectives (2008): 110-20, at 115-16.

34 The following are examples of operational guidelines for Ethiopian, Ghanaian and Zambian abortions laws, respectively: Family Health Department, Technical and Procedural Guidelines for Safe Abortion Services in Ethiopia (2006); Republic of Ghana, Prevention and Management of Unsafe Abortion: Comprehensive Abortion Care Services, Standards and Protocols (2006); Ministry of Health, Standards and Guidelines for Reducing Unsafe Abortion Morbidity and Mortality in Zambia (2009).

35 Prior to the 1977 Act, abortion in Zimbabwe was regulated by common law, itself a British and Roman-Dutch colonial inheritance. The Act, which was passed when the country was Rhodesia, was retained at independence in 1980: C. Ngwena, 'An Appraisal of Abortion Laws in Southern Africa from a Reproductive Health Rights Perspective', 32 Joumal of Law, Medicine \& Ethics (2004): $708-17$, at 713 . 
abortion, doctors are deterred from even performing abortions they believe to be lawful abortions for fear of prosecution, ${ }^{36}$ and partly because the law is not accompanied by guidelines or an administrative framework for addressing disputes timeously.

\section{B. Link with unsafe abortion}

The World Health Organization estimates that 47,000 women die each year from unsafe abortion, a figure accounting for 13 per cent of maternal mortality. ${ }^{37}$ The global prevalence of unsafe abortion demonstrates a sharp divide between the northern and southern hemispheres. In the Global North, unsafe abortion has been drastically stemmed, to the point of becoming a rare occurrence. ${ }^{38}$ Liberal reforms of abortion laws, accessibility of abortion services, together with vastly improved living standards have made safe abortion a real choice for women with unwanted pregnancies. Even in those few northern countries, such as Ireland, where abortion remains highly restricted, unsafe abortion has, notwithstanding, been mitigated mainly through women avoiding the rigours of the law by travelling to neighbouring countries to have abortions. ${ }^{39}$ In the Global South, on the other hand, unsafe abortion that is linked to highly restrictive laws, services that are inaccessible or non-existent and socio-economic deprivation remains a bane, claiming thousands of lives each year.

Almost all unsafe abortions occur in developing countries, ${ }^{40}$ with a quarter occurring in the Sub-Saharan region. ${ }^{41}$ Whilst the mortality rate of unsafe abortions per 100,000 unsafe abortions is 30 for the Global North, and 220 for the Global South as a whole, that of the Sub-Saharan Africa region is 520, making it the region with, by far, the highest mortality rate. ${ }^{42}$ Each year, around 29,000 African women die from unsafe abortion, bringing Africa's burden of

36 B. R. Johnson, S. Ndhlovu, S. L. Farr and T. Chipato, 'Reducing Unplanned Pregnancy in Zimbabwe through Postabortion Contraception', 33 Studies in Family Planning (2002): 195-202, at 195.

37 World Health Organization, Unsafe Abortion: Global and Regional Estimates of the Incidence of Unsafe Abortion and Associated Mortality in 2008, World Health Organization (2011), pp. 1, 27. According to the World Health Organization, unsafe abortion means a procedure for terminating an unintended pregnancy carried out either by individuals without the necessary skills or in an environment that does not conform to minimal medical standards or both. See World Health Organization, The Prevention and Management of Unsafe Abortion: Report of a Technical Working Group (1992).

38 It is important not to overgeneralise about the Global North. In some countries, notably the former Eastern European countries, the incidence of unsafe abortion is neither well researched nor properly documented, as has been noted in respect of Poland, for example. The CEDAW Committee has expressed concern over the lack of official data and research on prevalence of illegal abortion in Poland and its consequence on women's health and life. See The CEDAW Committee 37th Session, CEDAW/C/POL/CO/6 (2007), paras 24-5.

$39 A, B$ and $C$, supra note 25.

40 World Health Organization, Unsafe Abortion, supra note 37, p. 1; S. Singh, 'The Incidence of Unsafe Abortion: A Global Review', in Warriner and Shah, Preventing Unsafe Abortion and Its Consequences, supra note 4, pp. 35-50, pp. 38-9.

41 Singh, ibid., pp. 38-9.

42 World Health Organization, Unsafe Abortion, supra note 37, p. 30; Singh, ibid., p. 45. 
mortality rate from unsafe abortion to around 61 per cent of the global total. ${ }^{43}$ Women who survive unsafe abortion experience major illnesses and disabilities, including uterine perforation, sepsis, peritonitis, haemorrhage, chronic pelvic pain and secondary infertility. ${ }^{44}$ A high proportion (20-50 per cent) are hospitalised for complications. ${ }^{45}$ The cost to health systems of treating the complications of unsafe abortion far exceeds the cost of providing safe abortion services. ${ }^{46}$

Within Sub-Saharan Africa, there are socio-economic disparities to accessing safe abortion services. It is women that are poor or young or those that live in rural areas that are particularly vulnerable to unsafe abortion. ${ }^{47}$ Poverty deprives women of the means to afford safe abortion services that might be available in the private sector of their own countries notwithstanding highly restrictive laws, or much less, the means to travel to other jurisdictions for abortion services as do their counterparts in the Global North. Even where the law permits abortion, adolescents are more likely than their adult counterparts to delay or avoid accessing safe abortion services due to ignorance about pregnancy or availability of safe, legal services, and above all, the desire to conceal the pregnancy from the family and continue with school, and lack of means or capacity to afford, on their own, the cost of safe abortion services. ${ }^{48}$ Lack of youth-friendly sexual and reproductive healthcare services, and uncertainty among providers whether minors can legally access abortion services without the involvement of their parents serve as additional barriers to access. ${ }^{49}$ Amongst all regions, the SubSaharan region has the highest proportion of women aged 15-19 years who have recourse to unsafe abortion. ${ }^{50}$

While it is accessibility of safe abortion services that is ultimately decisive in reducing unsafe abortion, nonetheless, the law is an important enabling or disabling gateway to the provision of services. Highly restrictive abortion laws and practices serve as major catalysts for unsafe abortion. ${ }^{51}$ For these reasons, there is global as well as regional consensus on maximally using laws that permit abortion as well as liberalising abortion laws as important, if not essential, steps in the creation of an enabling environment for accessible safe abortion services. Though in 1994, the International Conference on Population and Development

43 World Health Organization, ibid., p. 28.

44 Grimes et al., 'Unsafe Abortion', supra note 1, at 1,910-12.

45 Ibid: S. Singh, 'Hospital Admissions Resulting from Unsafe Abortion: Estimates from 13 Developing World Countries', 368 Lancet (2006): 1,887.

46 Singh, ibid.

47 Singh, 'The Incidence of Unsafe Abortion', supra note 40, p. 44.

48 A. A. Ajayi, L. T. Marangu, J. Miller and J. M. Paxman, 'Adolescent Sexuality and Fertility in Kenya: A Study of Knowledge, Perceptions and Practices', 22 Studies in Family Planning (1991): 205-16; L. S Zabin and K. Kiragu, 'Health Consequences of Adolescent Sexuality and Fertility Behavior in Sub-Saharan Africa', 29 Studies in Family Planning (1998): 210-32.

49 Jackson et al., 'A Strategic Assessment of Unsafe Abortion in Malawi', supra note 29, at 139-40.

50 World Health Organization, Unsafe Abortion: Global and Regional Estimates of Incidence of Unsafe Abortion and Associated Mortality in 2003, World Health Organization (2007), p. 6.

51 Guttmacher Institute, Abortion Worldwide: A Decade of Uneven Progress, Guttmacher Institute (2009), pp. 25-9; M. Berer, 'National Laws and Unsafe Abortion: the Parameters of Change', 12 Reproductive Health Matters (2004): 1-8. 
(ICPD) fell short of calling for liberalisation of abortion laws, nonetheless, it implicated unsafe abortion as a 'major public concern' and a 'major threat to the health and lives of women'. ${ }^{2}$ In addition, at ICPD, governments agreed to provide abortion services where abortion is not against the law. ${ }^{53}$ A year later, the Fourth World Conference on Women saw governments agreeing on the need to consider reviewing laws that criminalise abortion. ${ }^{54}$ In 2003 , the World Health Organization (WHO) added international support towards removing legal obstacles to safe abortion by issuing guidance on standards that health systems and healthcare providers should adopt in order to render lawful abortion services accessible, including removing burdensome certification procedures for determining eligibility for abortion. ${ }^{55}$

It is significant that United Nations treaty monitoring bodies, in their Concluding Observations especially, have been advancing the global consensus on the social injustice of unsafe abortion treaty by implicating restrictive abortion laws as inextricably bound with violations of human rights to the extent that such laws provide incentives for unsafe abortion. In this way, UN treaty monitoring bodies have been instrumental in developing a jurisprudence that supports the evolution of framing abortion as a human right, albeit one that is incidental to the protection of the fundamental rights that are guaranteed under the various treaties, including the rights to health, life and equality, and the right not be subjected to cruel, inhuman and degrading treatment. ${ }^{56}$ Concluding Observations of various UN treaty monitoring bodies have been urging countries with restrictive abortion laws, not least African countries, ${ }^{57}$ to respond to the scourge of unsafe abortion and its adverse impact on human rights by reviewing their laws to expand the grounds for abortion.

For example, the CEDAW Committee has called upon Malawi to review its restrictive abortion law in order to stem its high mortality rate. ${ }^{58}$ The Committee on the Rights of the Child has urged Chad to liberalise its abortion law to prevent clandestine unsafe abortions particularly among adolescent girls. ${ }^{59}$ The Human

52 Programme of Action of the International Conference on Population and Development, 5-13 September 1994, Doc. ST/ESA/SER.A/149, paras 8.25, 12.17.

53 Ibid., at para. 8.25; A follow-up to ICPD in 1999, ICPD +5: Key Actions for the Further Implementation of the Programme of Action of the International Conference on Population and Development, UN GAOR, 21st Special Session, June 30-July 2, 1999, para. 63.

54 Beijing Declaration and Platform for Action, Fourth World Conference on Women, 4-15 September 1995, para. 106(k).

55 World Health Organization, Safe Abortion: Technical and Policy Guidance for Health Systems (2003).

56 C. Zampas and J. M. Gher, 'Abortion as a Human Right - International and Regional Standards', 8 Human Rights Law Review (2008): 249-94, at 255; Ngwena,' Inscribing Abortion as a Human Right', supra note 5, at 787-97.

57 Ngwena, ibid, at 792-3.

58 Concluding Observations of the Committee on the Elimination of Discrimination against Women, CEDAW/C/MWI/CO/6 (2010), paras 36-7.

59 Concluding Observations of the Committee on the Rights of the Child: Chad, adopted 4 June 1999, UN GAOR, Committee on the Rights of the Child, 21st Session UN Doc. CRC/C/15/Add.107 (1999), para. 30. 
Rights Committee has made similar observations in respect of the Gambia. ${ }^{60}$ Prior to its constitutional reform in 2010, Kenya's abortion law has been the subject of criticism by the Human Rights Committee, ${ }^{61}$ the Committee on the Rights of the Child, ${ }^{62}$ the CEDAW Committee ${ }^{63}$ and the Committee on Economic, Social and Cultural Rights, ${ }^{64}$ with all the committees converging on implicating the country's abortion law as a major contributor towards a high maternal mortality rate as well as recommending liberalisation of the law.

At the African regional level, the link between unsafe abortion and restrictive laws has been acknowledged mainly through the recognition of abortion as a human right in the substantive provisions of the Protocol to the African Charter on Human and Peoples' Rights the Rights of Women in Africa (Women's Protocol). ${ }^{65}$ Article 14(2)(c) of the Women's Protocol requires states parties to permit abortion in cases of 'sexual assault, rape, incest, and where continued pregnancy endangers the mental and physical health of the mother or the life of the mother or the foetus'. The unequivocal recognition of abortion as a fundamental right with a corresponding peremptory duty in an international treaty is a unique development. ${ }^{66}$ It can be understood as a clarion call aimed at breaking the silence on unsafe abortion and highlighting the urgency of remedial action at the regional level.

Of course, calls for liberalising abortion law through expanding abortion grounds are an important strategy for creating an enabling environment for access to safe abortion. But advocates of reform must also be aware that abortion law reform fails women if it merely secures a paper victory but remains hidden, doing little to reassure women that they have a real entitlement to abortion. Equally, reform fails women if it still leaves providers fearful of attracting prosecution for providing services that are otherwise lawful. Part of the problem with Kenya's abortion law, for example, is not so much that it has always been

60 Concluding Observations of the Human Rights Committee: The Gambia, adopted 23 July 2002 , UN GAOR, Human Rights Committee, 81st Session, UN Doc. CCPR/CO/75/GMB (2004), para. 17; Criminal Code of the Gambia, sections 140-2, 198-9.

61 Concluding Observations: Kenya, adopted 24 March 2005, UN GAOR, Human Rights Committee, 83rd Session, UN Doc. CCPR/CO/83/KEN (2005), para. 14. For constitutional reform of abortion in Kenya, see infra note 67.

62 Concluding Observations: Kenya. adopted 2 February 2007, UN GAOR, Committee on the Rights of the Child, 44th Session, UN Doc. CRC/C/KEN/CO/2 (2007), paras 49-50.

63 Responses to the List of Questions with Regard to the Consideration of the Combined Fifth and Sixth Periodic Report: Kenya, UN GAOR, Committee on Elimination of All Forms of Discrimination against Women, 39th Session, UN Doc. CEDAW/C/KEN/CO/2 (2007), paras 37-8; Concluding Observations: Kenya, adopted 2 February 2011, UN GAOR, Committee on the Elimination of All Forms of Discrimination against Women, 48th Session, UN Doc. CEDAW/C/KEN/CO/7 (2011), para. 38.

64 Concluding Observations: Kenya, adopted 19 November 2008, UN GAOR, Committee on Economic, Social and Cultural Rights, 41st Session, UN Doc. E/C.12/KEN/CO/1 (2008), para. 33.

65 Protocol to the African Charter on Human and Peoples' Rights on the Rights of Women in Africa, adopted 11 July 2003, 2nd Ordinary Session of the Assembly of the African Union, AHG/Res. 240 (XXXI), entered into force 25 November 2005 (hereinafter Women's Protocol).

66 Zampas and Gher, 'Abortion as a Human Right', supra note 56, at 250; Ngwena, 'Inscribing Abortion as a Human Right', supra note 5, at 810-11. 
highly restrictive in a strict legal sense, but that it has lacked transparency due to lack of implementation. Prior to the liberalisation of abortion by the Kenyan Constitution of $2010,{ }^{67}$ the Kenyan Penal Code, which is analogous to the English Offences Against the Person Act, was widely understood as highly restrictive. ${ }^{68}$ The understanding was that it permitted abortion only rarely, when the life of the pregnant woman was threatened. This conservative understanding is partly because, beyond appearance in a law report, a decision of the East African Court ${ }^{69}$ which received Bourne ${ }^{70}$ an English case, into East African jurisprudence, thus judicially liberalising abortion to include risk to the pregnant woman's health as a ground for abortion, was never implemented by the Kenyan legal or health systems. The recent liberalisation of abortion by the new Kenyan Constitution will equally fail women unless it is implemented in a transparent manner. ${ }^{71}$

Over and above liberalisation, what the African region needs is an approach to abortion law reform that is cognisant of the importance of transparency. In this connection, the Maputo Plan of Action for the Operationalisation of the Continental Policy Framework for Sexual and Reproductive Health and Rights (Maputo Plan of Action) comes close to grasping the nettle. ${ }^{72}$ The Maputo Plan of Action is Africa's regional strategy for achieving Millennium Development Goals (MDGs) ${ }^{73}$ and, in particular, achieving the goal of universal access to comprehensive sexual and reproductive services in the region by 2015 . Reducing unsafe abortion is one of the plan's key strategies. To this end, the plan, inter alia, requires governments to enact policies and legal frameworks to reduce unsafe abortion. ${ }^{74}$ From a transparency standpoint, it is significant that, over and above requiring governments to train service providers in the provision of comprehensive safe abortion services where domestic laws allow, ${ }^{75}$ and to provide safe abortion services to the 'fullest extent of the law', ${ }^{76}$ the plan also requires

67 Article 26(4) of the Kenyan Constitution permits abortion on grounds of: emergency medical treatment; danger to the life or health of the pregnant woman; or if abortion is permitted by any other written law.

68 Kenyan Penal Code, sections 158, 159 \& 240; Centre for Reproductive Rights, In Harm's Way: Impact of Kenya's Restrictive Abortion Law (2010), pp. 16-17.

69 Mehar Singh Bansel v $R$ (1959) East African Law Reports 813.

$70 R v$ Boume 1 Kings Bench 687 (1938).

71 In September 2012, the Kenyan Ministry of Medical Services published, for the first time, guidelines that are intended to implement abortion law following the reform of abortion law by the Kenyan Constitution. The guidelines - Standard Guidelines for Reducing Morbidity and Mortality from Unsafe Abortion in Kenya (2012) - inter alia, serve to explain the eligibility criteria for abortion, and to guide healthcare professionals in their discharge of constitutional obligations which are owed to women seeking abortion.

72 African Union, Maputo Plan of Action for the Operationalisation of the Continental Policy Framework for Sexual and Reproductive Health and Rights 2007-2010 (2006).

73 United Nations Millennium Declaration, adopted 18 September 2000, GA Res. 55/2, UN GAOR 55 th Session (2000). Goal 5a of the MDGs seeks to reduce by 75 per cent maternal mortality by 2015 while Goal 5b seeks to achieve universal access to reproductive health by 2015 .

74 Maputo Plan of Action, supra note 72, at para. 4.1.2a.

$75 \mathrm{Ibid}$, at para. 4.2.1a.

76 Ibid., at para. 4.3.1a. 
governments to educate communities about available safe abortions services as allowed by domestic laws. ${ }^{77}$

\section{TRANSPARENCY IN ABORTION LAWS AS PROCEDURAL EQUALITY: ARGUMENTS FROM RAWLS' OVERLAPPING CONSENSUS}

The case for transparency in this section is framed around John Rawls' philosophical idea of an 'overlapping consensus'. ${ }^{78}$ The argument is that transparency is an integral part of an overall agreement among citizens who otherwise disagree about the moral rightness or wrongness of abortion. The appropriation of Rawls' argument in this section makes three main assumptions. First, it assumes that the African region is committed to the ideals of liberalism even if, from time to time, lapses in democratic governance in individual countries undermine this commitment. The 1990s, especially, partly as one of the effects of the end of the Cold War, saw many African countries abandon one-party states to commit themselves to multi-parties and democratic governance. ${ }^{79}$ This transition was accompanied by domestic constitutional reforms that sought to restore traditional civil liberties. The establishment of the African Union in 2000 to supplant the Organization of African Unity underpinned the region's constitutional commitment to democracy. ${ }^{80}$ The promotion of 'democratic principles and institutions' is one of the founding objectives of the Union. ${ }^{81}$ The same applies to the promotion and protection of human rights. ${ }^{82}$

The second assumption is that consensual reform of substantive abortion law is hard, if not impossible, to achieve even in a liberal democracy because of respect for pluralism. The third assumption is that stability and social unity in a democracy are based not so much on a certain shared conception of the good emanating from a comprehensive philosophical or moral doctrine, but rather on certain shared principles of justice. ${ }^{83}$ These are principles that are universally shared and are not dependent on self-interest or a coincidence of group interests. ${ }^{84}$ The principles are not dependent upon whether a particular moral position on abortion ought to be vindicated by the law but, rather, on consensus about the nature and purpose of legal right in a constitutional democracy that seeks to achieve stability and social unity. ${ }^{85}$

77 Ibid., at para. 4.3.2a.

78 Rawls, Political Liberalism, supra note 7, pp. 133-72.

79 R. Murray, Human Rights in Africa, Cambridge University Press (2004), pp. 73-115; F. Viljoen, International Human Rights Law in Africa, Oxford University Press (2007), p. 169.

80 Constitutive Act of the African Union 2000.

81 Ibid., article $3(\mathrm{~g})$.

82 Ibid., article $3(\mathrm{~h})$.

83 Rawls, Political Liberalism, supra note 7, pp. 133-4.

84 Ibid., p. 147.

85 Ibid., pp. 1404. 


\section{A. Explaining the nexus between Rawls' overlapping consensus and the duty of transparency}

It is easy to see why a shared conception about the morality of abortion cannot be achieved. Abortion has always engendered dichotomous and polarised reactions. ${ }^{86}$ It is not possible to find a liberal democracy that has ever achieved the feat of consensual reform of abortion. ${ }^{87}$ The critical ethical question which generates controversy about the legality of abortion principally revolves around when life begins. This question cannot be answered from a position of neutrality precisely because neutrality in abortion is an epistemic impossibility. ${ }^{88}$ The controversy in abortion is about morality and, as Ana da Costa e Fonseca has argued, there can never be a neutral point of view regarding morality. ${ }^{89}$ Thus, logic cannot change moral positions on abortion. Each argument, including that of viability, comes already invested with logic that is internal only to itself and is, perforce, subjective. Scientific concepts and the judicial construction of abortion or its constitutionalisation cannot bridge what is, in the first place, an unbridgeable moral dichotomy which at its extreme end, as Lawrence Tribe put it, is a clash of absolutes..$^{90}$ Any claim to neutrality or objectivity about the substantive law on abortion is apt to be arbitrary and merely rhetorical. Any such claim will always be tethered to moral subjectivity that is created by human beings with different needs in a world where there are no absolute moral values and no metaphysical certainties. If this dichotomy is the backdrop of our comprehensive philosophical doctrines about abortion, the question is: how do we move forward?

One way of moving forward is through reaching agreement not so much on the substantive morality of abortion, as this is impossible, but, rather, on the principles of justice that should govern any abortion regime in a democracy. At the very least, it is submitted, we ought to agree that in those instances where a particular jurisdiction which is committed to constitutional governance chooses to regulate abortion by generally prohibiting abortion, but permitting it in certain given circumstances as, indeed, is the global trend, then any such permission should be given real effect as part of our overlapping consensus so that it bestows tangible rights and duties. It is a consensus that is derived from what it means, or more accurately, what it ought to mean to have rights as claims with corresponding duties in a constitutional democracy.

In a democracy, stability and social unity or cooperation are achieved through a shared conception of justice where one of the fundamental intuitive ideas is that of a political system that is fair between citizens who are entitled to equal basic rights and liberties. Part of Rawls' august contribution to twentieth-century philosophical theorisation of justice was his idea of an

86 L. H. Tribe, Abortion: The Clash of Absolutes, W.W. Norton (1990), p. 1.

87 S. A. M. McLean, 'Abortion Law: Is Consensual Reform Possible?', 17 Journal of Law and Society (1990): 106-23.

88 A. C. da Costa e Fonseca, "The Fallacy of Neutrality: The Interruption of Pregnancy of Anencephalic Fetus in Brazil', 25 Bioethics (2011): 458-62, at 462.

89 Ibid.

90 Tribe, Abortion, supra note 86, p. 1. 
'overlapping consensus', which he posited as a political conception of justice in a constitutional democracy. ${ }^{91}$ Though Rawls advanced the idea of overlapping consensus primarily as a principle for the organisation of political and social institutions, it is possible to argue that the requirement of transparency can be understood as an expression of overlapping consensus about equality under the law even if we share different views about the moral rightness or wrongness of abortion.

In abortion, as in Rawls' assumptions about the historical and social conditions in a modern democracy, we start off with the imperative of not only taking cognisance of, but also respecting, pluralism. Rawls begins with acknowledging opposing religious, philosophical and moral doctrines as doctrines that ought to be affirmed rather than oppressed. ${ }^{92}$ He accepts that pluralism is not a mere historical condition or ephemeral phenomenon that will soon pass but, rather, is a permanent feature of public culture in modern democracies. ${ }^{93}$ Taking into account the reality of pluralism and incommensurable conceptions of a good life, Rawls' goal or idea of an overlapping consensus is to come up with a principled, rather than expedient or self-serving basis or modus vivendi for regulating public life in a manner that is conducive to continuity from one generation to the next. ${ }^{94}$ The rationale for overlapping consensus is that despite pluralism, and despite deep divisions, a constitutional democracy needs a publicly recognised and reasoned principle in the form of a reasonable conception of justice that applies to the basic structure of society to enable that society not so much to avoid futility, but to achieve stability and social unity among citizens who are free and equal. ${ }^{95}$

Admittedly, equality is protean in character. $^{96}$ At the same time, equality is a fundamental intuitive value and idea from which to construct a reasonable political conception of justice, as, indeed, Rawls sought to do in his larger work, Theory of Justice. ${ }^{97}$ Irrespective of our views about the rightness or wrongness of abortion, at the very least, it should be possible to agree that equality under the law is a shared consensus in a constitutional democracy because it seeks to ensure fairness between citizens that are free and equal. ${ }^{98}$ Furthermore, we can agree that part of how we can ensure equality of opportunity is through promoting rights consciousness among individuals or social groups that are disadvantaged and have historically been denied a certain right that is now guaranteed. ${ }^{99}$ This is

91 Rawls, Political Liberalism, supra note 7, pp. 133-72.

92 Ibid., p. 135.

93 Ibid., p. 136.

94 Ibid., pp. 147-8.

95 Ibid., p. 142.

96 R. M. Veath, The Foundation of Justice, Clarendon Press (1986), p. 119.

97 J. Rawls, Theory of Justice, Oxford University Press (1971).

98 Though Rawls does not construct a list of the intuitive values that inform or ought to be regarded as informing a reasonable conception of justice, it is clear that he accepted a liberal conception of equality as one of the pillars of a reasonable conception of justice. It is justice as fairness among 'free and equal' citizens that is the impulse behind Rawls' idea of an overlapping consensus.

99 M. Minow, 'Interpreting Rights: An Essay for Robert Cover', 96 Yale Law Journal (1987): 1,860-915, at 1,867; P. Gable, 'The Phenomenology of Rights-consciousness and the Pact of Withdrawn Selves', 62 Texas Law Review (1984): 1,563-99, at 1,590. 
more compelling in those cases where requiring the State to enable the effective realisation of rights does not impose a heavy or undue financial burden on it. In other words, if it is within the available resources of the State to render legal rights tangible so that they can be equally and effectively enjoyed by the beneficiaries, a consensus to impose a duty of transparency on the State should not be hard to muster. Such a consensus becomes part of the juridical translation of a wider reasonable political conception of justice that intuitively appeals to the imperative of fair system of social cooperation between citizens that enjoy equal protection under the law.

It is significant that, over and above the requirement of being liberal, Rawls argued that a reasonable conception of justice should seek to protect the familiar basic rights and assign them special priority, taking into account that not all individuals in a society will be able, on their own, to realise the guaranteed basic rights. ${ }^{100}$ According to Rawls, part of assigning special priority to rights of importance, such as equality under the law, requires the adoption of measures to ensure that all persons, as part of equal opportunities, have sufficient material means to make effective use of the basic rights. ${ }^{101}$ In this instance, the argument is that the discharge of the duty of transparency is a constituent component of how the State provides citizens with sufficient means to make effective use of basic rights. Equally, the provision of accessible opportunities or mechanisms for allowing citizens to challenge official decisions that refuse certain legal claims is a component of how the State makes good its promise to guarantee equal opportunities.

\section{B. Emerging jurisprudence supporting overlapping consensus}

More than any other court, the European Court of Human Rights has been pioneering the development of abortion jurisprudence that implicitly supports the notion of an overlapping consensus. In three cases, Tysiac $v$ Poland, ${ }^{102} A, B$ and $C$ v Ireland ${ }^{103}$ and $R$. R. v Poland, ${ }^{104}$ the Court has used transparency-related state duties as juridical standards for determining whether domestic abortion laws comply with the European Convention on Human Rights. The background to the three cases is that the Court has adjudicated abortion-related claims on the basis that, substantively as well as procedurally, such claims primarily implicate article 8 of the European Convention, which guarantees the right to privacy. According to the Court, the right to privacy is broad enough to encompass a woman's autonomy to decide whether to have an abortion. ${ }^{105}$ At a substantive level, the Court has

100 Rawls makes this clear in the original essay on overlapping consensus: J. Rawls, 'The Idea of an Overlapping Consensus', 7 Oxford Journal of Legal Studies (1987): 1-25, at 17-18.

101 Ibid.

102 Tysiac v Poland, App. No. 5410/03, ECHR 2007-IV (2007).

$103 A, B$ and C, supra note 25.

104 R. R. v Poland, App. No. 27617/04 (2011).

105 Tysiac v Poland, supra note 102, at paras 105-7; A, B and C, supra note 25, at paras 212-14; R. R. v Poland, ibid., at paras $179-81$. 
stopped short of recognising a woman's right to abortion as a fundamental right. It has interpreted article 8 conservatively and in a manner that concedes a very wide margin of appreciation to national authorities, including upholding domestic law that recognises a substantial risk to the life of the pregnant woman as the only permissible ground for abortion. ${ }^{106}$ At the same time, the Court has begun to insist on certain minimum procedural guarantees. It is from these procedural guarantees that it can be argued that the Court's jurisprudence supports the idea of an overlapping consensus that the African region can tap into.

The essence of the overlapping consensus under the European Convention is that once a legislature decides to allow abortion, it must not structure its legal framework in a way that effectively undermines the real possibilities of exercising the rights permitted under the law. ${ }^{107}$ Instead, the State must implement the law in a way that is conducive to realisation of any recognised abortion rights. Rather than merely treat article 8 as imposing a state duty of restraint, that is, a duty not to interfere with a woman's decision about whether to have a child or continue with a pregnancy, depending on how national authorities substantively exercise their margin of appreciation, the Court has also said that article 8 implicitly imposes a positive duty, whatever the nature of substantive domestic abortion law. The Court has read into article 8 a positive duty of the State to ensure the effective realisation of any abortion rights that it guarantees.

In Tysiac $v$ Poland, an applicant who had been denied abortion under the Polish healthcare system brought a challenge before the European Court of Human Rights. The applicant suffered from a retinal condition. She had requested abortion on the ground of threat to her health. She feared that continuing with the pregnancy would worsen her retinal condition. Polish law provided that 'abortion can be carried out by a physician where pregnancy endangers the mother's life or health' ${ }^{108}$ Her request was denied on the ground that her retinal condition did not meet the health ground.

Polish abortion law prescribes certification requirements in two ways. It provides that a consultant specialising in the field of medicine relevant to the pregnant woman's condition must first certify that a ground for abortion has been met. ${ }^{109}$ It also provides that where abortion is sought on the ground of a danger to the health or life of the pregnant woman, a doctor, other than the one who is to perform the abortion, must certify that the eligibility requirements under the law have been met. ${ }^{110}$ Doctors could not agree on whether the applicant had met the legal requirements. While the applicant's general practitioner certified that she met the health ground for abortion, two ophthalmologists were of the opinion that the

$106 A, B$ and $C$, ibid., upholding Irish abortion law as contained in Article 40.3 .3 of the Irish Constitution and as decided by the Irish Supreme Court in Attorney General $v X$ and Others, supra note 26.

107 Tysiac v Poland, supra note 102, at para. 116.

108 Polish Family Planning (Protection of the Human Foetus and Conditions Permitting Pregnancy Termination) Act 1993 (hereinafter Polish Family Planning Act), section 4(a), para. 1.

109 Ordinance issued by the Polish Minister of Health on 22 January 1997, section 2.

110 Polish Family Planning Act, supra note 108, section 4(a), para. 5. 
pregnancy did not constitute a sufficient risk to her retinal condition. Furthermore, a gynaecologist that she consulted was of the view that the applicant did not meet the legal requirements. In the end, because of the disagreement among doctors, she was refused abortion. The applicant carried the pregnancy to term, but thereafter suffered further deterioration of her retinal condition to the extent of losing much of her sight and being certified as 'significantly disabled'. ${ }^{111}$ Basing its decision on an interpretation of article 8 of the European Convention on Human Rights, it was held by the Court that the Polish State was in breach of its positive duty to ensure that domestic abortion law was implemented in a manner that allowed the applicant to realise her rights effectively.

In Tysiac, the main shortcoming, according to the Court, was the failure by the Polish State to put in place adequate procedural and institutional mechanisms for regulating access to lawful abortion. Alluding to the concepts of lawfulness and the rule of law in a democratic society, the Court highlighted that, other than the option of litigation, there were no provisions for bringing the matter before an independent body to review any disagreement between the woman and doctors after hearing the woman and considering her views. ${ }^{12}$ Though an important safeguard, the Court did not regard litigation as sufficient recourse for the woman because 'time is of critical importance'. ${ }^{113}$ Litigation, which takes the form of a post factum review of decisions concerning abortion, was of little avail since women seeking abortion do not wish to become mothers in the first place. ${ }^{114}$ According to the Court, there was a need to ensure that women are given a fair opportunity to make a timely decision about abortion, including avoiding late abortions, which come with increased health risks ${ }^{115}$ In this sense, the Court linked implementation of abortion law with the need for responsive administrative justice. It said that since disagreements are apt to arise between the woman seeking abortion and doctors or between doctors, the 'applicable legal provisions must, first and foremost, ensure clarity of the pregnant woman's legal position' ${ }^{116}$ Clarity is an important consideration, not least because the criminal regulation of abortion coupled with the risk of incurring criminal responsibility could well have a 'chilling effect' on doctors when deciding whether a woman seeking abortion meets the legal requirements. ${ }^{117}$

In $A, B$ and $C v$ Ireland, ${ }^{118}$ which was discussed earlier, the European Court of Human Rights followed its own decision in Tysiac $v$ Poland and underlined the place of transparency in the implementation of abortion law. The Court highlighted that Irish abortion law was lacking in administrative justice. Short of litigation, there was no institutional framework for reviewing differences of

111 Tysiac v Poland, supra note 102, at para. 18.

112 Ibid., at para. 117.

113 Ibid., at para. 118.

114 Ibid.

115 Ibid.

$116 \mathrm{Ibid}$, at para. 116.

117 Ibid.

$118 A, B$ and $C$, supra note 25. 
opinion between the woman and doctors or between doctors. ${ }^{119}$ The Court could not consider the normal process where a woman seeking abortion consults a doctor as an adequate and effective means of determining whether the woman meets the legal grounds for abortion. ${ }^{120}$ Equally, the Court could not consider litigation as the appropriate institutional mechanism for the primary determination of whether a woman qualifies for abortion which is lawfully available under domestic law, partly because courts would only be able to resolve disputes on a case-by-case basis. ${ }^{121}$ It was not expected of women to take on the complexity of constitutional proceedings as a regular means of vindicating a right to abortion under domestic law. ${ }^{122}$

Though linked to abortion, the claim in $R$. R. v Poland ${ }^{123}$ was not about denial of abortion as such. Rather, it was about denial of timely access to diagnostic procedures that were relevant to the applicant's decision whether to have an abortion. When the applicant was in her eighteenth week of pregnancy, an ultrasound scan had revealed that the foetus might be suffering from malformations; however, her efforts to secure confirmatory diagnosis were severely impeded despite her entitlement to access to prenatal diagnostic information under domestic law. ${ }^{124}$ The impediments were partly the result of antipathy towards abortion, with some doctors purportedly basing their refusal to provide diagnostic services on the right to conscientious objection. In part, the impediments were to do with administrative confusion in the Polish healthcare system about procedures for providing the diagnostic services. By the time that the applicant had access to genetic testing, she was told that she was now outside the legal time limit for abortion. ${ }^{125}$ In the end, the applicant carried the pregnancy to term and gave birth to a child affected with Turner syndrome, a genetic condition which manifests in females, causes severe illnesses and requires life-long medical care.

The Court found that the applicant's determination to have timely access to diagnostic testing was 'marred by procrastination, confusion and lack of proper counseling and information' on the part of the Polish healthcare system. ${ }^{126}$ In the end, she was denied the opportunity to decide about abortion within the time limit under Polish law. ${ }^{127}$ The Court reiterated its observation in $A, B$, and $C v$ Ireland that though the State has a broad margin of appreciation regarding the circumstances in which abortion is permitted, once it has decided to permit abortion, it ought to devise its legal system in a manner that allows the right

119 Ibid.

120 Ibid., at para. 255.

121 Ibid.

122 Ibid., at para. 259.

123 R. R. v Poland, supra note 104.

124 Polish Family Planning Act, supra note 108, section 2(a).

125 Under Polish Family Planning Act, ibid., section 4(a), terminations on the ground of risk to foetal health or foetal life can be performed any time before the foetus is capable of surviving outside the woman's body.

126 R. R. v Poland, supra note 104, at para. 153.

$127 \mathrm{Ibid}$., at para. 204. 
to abortion to be adequately realised. ${ }^{128}$ In this instance, there was no adequate legal and procedural framework to guarantee the applicant adequate and timely access to diagnostic information, ${ }^{129}$ nor a procedural framework to address any dispute between the pregnant woman and doctors or between doctors. ${ }^{130}$ Noting that some doctors had refused to offer the applicant diagnostic tests or a referral on the ground of conscientious objection to abortion, the Court emphasised that there was a duty upon the State to organise health services in a manner which ensures that exercise of the freedom of conscience does not prevent patients from accessing services to which they have a legal entitlement. ${ }^{131}$ The Court held that there was a breach not only of the procedural requirements of article 8 of the Convention, but also of the substantive provisions of article 3 which, inter alia, guarantees freedom from inhuman and degrading treatment.

The decisions of the European Court of Human Rights in Tysiac v Poland, $A, B$ and $C \vee$ Ireland and $R$. R. v Poland, in which transparency has emerged as an important juridical concept and human right in adjudication of abortion rights claims, can be understood as ultimately appealing to Rawls' overlapping consensus about the procedural content of individual rights in member states that are committed to liberal democracy as a regional principle. The Court's unequivocal insistence on the need for abortions laws that are effective rather than illusory and the need for accessible and timely procedures for addressing and resolving any dispute that arises from an attempt to exercise abortion-related rights can, in the light of the historical marginalisation of abortion rights, be understood as a consensus about equal treatment under the law.

Though the European Court of Human Rights has given transparency in abortion its most visible juridical space, it serves well to note that transparency has also been used by a domestic court ${ }^{132}$ and United Nations treaty bodies ${ }^{133}$ to vindicate abortion-related rights. The decision of the Court of Appeal for the United Kingdom in Family Planning Association of Northern Ireland, ${ }^{134}$ that was discussed earlier, supports the proposition that the realisation of any given rights attendant to abortion is an integral feature of equality and fairness in a liberal democracy in which there ought to be respect for the rule of law. ${ }^{135}$ What is instructive about the backdrop to the litigation in this case is that it was part of the applicants' deliberate strategy to attempt to secure the rights of women seeking abortion not so much by persuading the court to change the substantive law or

128 Ibid., at paras 187, 200.

$129 \mathrm{Ibid}$., at paras $200,203$.

130 Ibid., at para. 207.

$131 \mathrm{Ibid}$., at para. 206.

132 Family Planning Association of Northern Ireland, supra note 23.

133 K. L. v Peru, Communication No. 1153/2003, adopted 24 October 2005, UN GAOR, Human Rights Committee, 85th Session, UN Doc. CCPR/C/85/D/1153/2003 (2005); L. C. v Peru, Communication No. 22/2009, CEDAW/C/50/D/22/2009 (2011); L. M. R. v Argentina, Communication No. 1608/2007, CCPR/C/101/D/168/2007, Human Rights Committee (2011).

134 Family Planning Association of Northern Ireland, supra note 23; Fletcher, 'Abortion Needs or Abortion Rights?' supra, note 33.

135 Fletcher, ibid, at 124. 
by relying on any fundamental rights under an international treaty, ${ }^{136}$ but, rather, by framing their case around the duty of the State to clarify the law as part of its accountability to citizens as the intended beneficiaries of duties incumbent on the State. In this way, the case ultimately appeals to the notion of an overlapping consensus.

Regarding UN treaty monitoring bodies, the decision of the Human Rights Committee in K. L. v Peru ${ }^{137}$ under the Optional Protocol to the International Covenant on Civil and Political Rights (ICCPR) is supportive of the notion of a duty of transparency. In that case, the Human Rights Committee held that denial of abortion by Peruvian authorities to the applicant, who was an adolescent who was pregnant with an anencephalic foetus, constituted, inter alia, violations of the rights to articles 2 (right to an effective remedy), 7 (right to be free from cruel, inhuman or degrading treatment), 17 (right to privacy) and 24 (right to special protection as a minor) of the ICCPR. Though the Peruvian Criminal Code criminalised abortion, it provided for the pregnant woman's life or health as exceptions. ${ }^{138}$ But despite these exceptions, and despite evidence that continuing with the pregnancy would pose significant risk to the health and life of the applicant, she was nonetheless denied abortion. The decision of the Human Rights Committee was based, in part, on the finding that there has been a failure by the Peruvian State to translate the Criminal Code into a legal or administrative framework for regulating abortion and vindicating any attendant rights. ${ }^{139}$

In L.C. v Peru,${ }^{140}$ the CEDAW Committee, inter alia, used transparency to find Peru in breach of its obligations under the CEDAW. It has found abortion law under the Peruvian Penal Code to manifestly lack a regulatory and independent administrative framework for vindicating entitlement to abortion in a timely manner where an initial request had been refused by a provider as to breach state obligation under CEDAW. Echoing the approach of the European Court of Human Rights in Tysiac $v$ Poland,${ }^{141}$ the Committee has said that where a state party has legalised abortion, it must establish an appropriate legal framework to enable not just women to effectively vindicate their rights, but also health professionals to provide lawful services. ${ }^{142}$ Furthermore, such a legal framework must be responsive to time being of the essence in decisions to terminate pregnancy. ${ }^{143}$ It must include a mechanism for 'rapid decision-making', a right to be heard and a right to appeal. ${ }^{144}$

136 Ibid., at 125.

137 K. L. v Peru, supra note 133.

138 Penal Code, article 119.

139 K. L.v Peru, supra note 133, at para. 5.2.

140 L. C. v Peru, supra note 133.

141 Tysiac v Poland, supra note 102.

142 L. C. v Peru, supra note 133, at para. 8.17.

143 Ibid.

144 Ibid. 
The approach of the Human Rights Committee in $L . M . R . v$ Argentina $^{145}$ under the Optional Protocol to the ICCPR also appeals to transparency as an underpinning legal value. In this case, a complainant who was 19 years of age but with a mental age of $8-10$ years, had become pregnant following a suspected rape. When, through her mother, she requested abortion from Argentinian hospital authorities, she was denied, notwithstanding that her request met the requirements for abortion under domestic law. Article 86(2) of the Argentinean Criminal Code permits abortion on the ground of danger to the life or health of the pregnant woman or if the pregnancy results from rape or indecent assault. Instead, the complainant was required to first obtain judicial authorisation. A first instance court refused her request for judicial authorisation and this was confirmed by a higher court. On appeal to the Supreme Court, she was successful. The Supreme Court ruled that judicial authorisation was unnecessary as the complainant met the legal eligibility criteria for abortion. Despite this ruling, she was unable to find a public health facility willing to terminate her pregnancy. In the end, with the support of women's organisations, her mother successfully arranged to have the pregnancy terminated clandestinely. The Human Rights Committee found that denial of abortion by Argentinian authorities constituted violations of article 2(3) (right to an effective remedy) taken together with articles 3 (right to equal enjoyment of rights), 7 (right to be free from inhuman and degrading treatment) and 17 (right to privacy). In reaching its findings in respect of article 2(3) especially, the Committee emphasised that Argentina had failed to provide an administrative framework for providing women seeking abortion under the Criminal Code with an effective remedy. ${ }^{146}$

An important lesson for advocates of African abortion law reform that can be drawn from the jurisprudential development on transparency by the European Court of Human Rights and UN treaty monitoring bodies is that reform of domestic abortion law need not always be organised around the assumption that changing the substantive law is the only route, as this might prove intractable or engender gratuitous opposition from vested interests. Reform can also take the path less travelled, namely, requiring governments to clarify the law and provide guidelines for its implementation with a view to securing the maximal utilisation of laws that permit abortion, however minimal the permission. Where governments fail to discharge this duty, comparative jurisprudence can be treated as a persuasive authority not just by African regional treaty bodies such as the African Commission on Peoples' and Human Rights, and the African Court on Human and Peoples' Rights, but also by national courts precisely because the transparency rationale in the jurisprudence does not depend on founding a new distinct abortion right. Rather, it appeals to an overlapping consensus about the duty of the State and its organs to respect, protect and fulfil rights in a democracy whatever the nature of the given right. 


\section{ARGUMENTS FROM SUBSTANTIVE EQUALITY}

Treating transparency in abortion as a substantive equality issue is aimed at accommodating the needs of women as women. It entails, as Rebecca Cook and Susannah Howard have argued, developing an antidiscrimination theory that seeks to affirm women by responding to the differences that women's reproductive capacities make and to the differences in the construction of women's life chances that are consequent upon reproductive capacities. ${ }^{147}$ Substantive equality focuses on outcomes or results. It is an understanding of (in)equality that is rooted in political, social and economic disparities between social groups. ${ }^{148}$ The overall aim is to transform structural inequality by eradicating systemic inequalities. In the abortion context, substantive equality enjoins looking at the lived equality of women who seek a health service that has been historically criminalised and stigmatised and might still be inaccessible even if the letter of the law permits it. Thus, it is not enough to measure equality by the mere fact that a jurisdiction has laws that recognise a right to choose abortion. Part of how substantive equality can be measured is by going further to ascertain whether law that recognises a right to abortion is in fact accessible and realisable by women seeking abortion services. Examining, especially, how subaltern groups - the most vulnerable, marginalised, socio-economically disadvantaged and the least-educated women experience pathways to abortion law and services and how the pathways impact on their health, life and agency becomes a dependable and egalitarian barometer for measuring equality in a society in which gendered structural equality especially subsists.

The main argument in this section is that, as an alternative to the imperative of procedural equality, the case for transparency can also be based on substantive equality. It can be based on the type of information and legal institutions that women seeking abortion in the African region need in order to achieve meaningful equality in a liberal democracy even if such information and legal framework is not needed by any other social group. To advance the argument, this section draws from Nancy Fraser's critical theory of 'recognition' and the 'capabilities' approach of Martha Nussbaum and Amartya Sen.

\section{A. Transparency as Fraser's status recognition of women}

Nancy Fraser's critical social theory of recognition has relevance for abortion even if Fraser has not addressed abortion specifically. Using Fraser's theoretical framework, women's struggles for access to abortion can be characterised as struggles for cultural as well as economic 'recognition'. ${ }^{149}$ Criminalisation of a health service, such as abortion, that only women need can be understood

147 Cook and Howard, 'Accommodating Women's Differences', supra note 6, at 1,040-1.

148 C. Albertyn, 'Substantive Equality and Transformative Equality in South Africa', 23 South African Journal on Human Rights (2007): 253-76, at 253.

149 Fraser, Justice Interruptus, supra note 10, pp. 11-39. 
as an instance of the 'misrecognition' of women. ${ }^{150}$ It is misrecognition that is ultimately tethered to structural inequality in a gendered world in which the political and economic interests of women are marginalised. Cook and Howard allude to misrecognition when they highlight how abortion laws have historically failed to accommodate women, and have been used to justify discrimination against women through neglect of health services that only women need, the enforcement of customary roles of women as mothers and self-sacrificing caregivers, and denial of agency. ${ }^{151}$ The requirement of transparency in abortion law can be analysed as an incident of redistributive justice that seeks to repair the misrecognition of the reproductive needs of women in order to secure parity in the socio-economic participation of women.

Fraser's theory of recognition speaks to social justice in which there is participatory parity. ${ }^{152}$ We can characterise women seeking abortion as belonging to a 'bivalent category'. ${ }^{153}$ It is a social group that seeks collective and holistic affirmation for the reason that it has historically endured both cultural and economic harms of deprivation that are rooted in gender inequalities that impede participatory parity. Thus, repairing the injustice of the historical criminalisation and stigmatisation of abortion, including the chilling effects of criminalisation, entails not only recognising the moral agency of women as expressed in formal equality, but also taking positive steps to provide services, including information about the legality of abortion that women, in particular, need so as to not only be culturally affirmed, but also to be empowered to overcome socio-economic disadvantages. Requiring legislatures and healthcare systems to provide women seeking abortion with sufficiently clear information about abortion and timeous administrative procedures for vindicating their rights becomes a way of achieving 'status recognition' in a democracy where the ethic of parity in participation is a major edifice. ${ }^{154}$ Transparency becomes part of implementing an 'institutional prerequisite of participatory parity' that is of critical importance to African women. ${ }^{155}$

In her essay on rethinking recognition, Nancy Fraser has argued against a model of recognition that draws its impulse only from a Hegelian model of identity for the reason that it would be an insufficient tool for realising a more durable recognition claim. ${ }^{156}$ Instead, Fraser urges us to think about misrecognition rather more in terms of 'status subordination'. In this way, we are able to register a misrecognition claim that draws sustenance from a 'status model' that is rooted in the imperative of remedying not just the injustice of demeaning cultural

150 Ibid.

151 Cook and Howard, 'Accommodating Women's Differences', supra note 6, at 1,040.

152 S. Liebenberg, 'Needs, Rights and Transformation: The Adjudication of Social Rights in South Africa', in T. Lovell (ed.), (Mis)Recognition, Social Inequality and Social Justice: Nancy Fraser and Pierre Bourdieu, Routledge (2007), pp. 177-201.

153 Fraser, Justice Interruptus, supra note 10, pp. 16-23.

154 Fraser, 'Rethinking Recognition', supra note 10, at 113-16.

155 Fraser and Honneth, Redistribution or Recognition?, supra note 10, p. 229.

156 Fraser, 'Rethinking Recognition', supra note 10, at 112-13. 
representations, but even more significantly, the socio-economic injustice of structural inequality. ${ }^{157}$ In building her argument, Fraser says:

Misrecognition, accordingly, does not mean the depreciation and deformation of group identity, but social subordination - in the sense of being prevented from participating as a peer in social life. To redress this injustice still requires a politics of recognition, but in the 'status model' this is no longer reduced to a question of identity: rather it means a politics aimed at overcoming subordination by establishing the misrecognised party as a full member of society, capable of participating on a par with the rest. ${ }^{158}$

Fraser's argument is ultimately a call for substantive equality that is predicated on the imperative of redistributive justice. Her concept of recognition is a theory of justice that is intended to guarantee participatory parity not through the divergent philosophical provenances of redistribution and recognition, but through their integration and symbiosis. ${ }^{159}$

Fraser rejects formal notions of equality as they promise misrecognition by according similar treatment to individuals and social groups in unequal positions. To meet Fraser's requirements of social justice, abortion regimes must meet two conditions. First, in their form and institutional implementation, they must recognise the needs of women who on account of the chilling effects of criminalisation are apt to assume that abortion is illegal even where it is actually permitted, and in consequence are denied an opportunity to realise a legal right. In the second place, abortion regimes must have a redistributive element. They must accord women resources that are necessary to realise their rights, taking into account that even as a class, women are not a homogeneous group. Some women, especially those who are poor, live in rural areas or have the least education, have greater information and institutional needs than others and will need commensurate resources in order to level the playing field.

It is important to stress that in Fraser's theory of recognition, the resources that are needed in order to achieve participatory parity are determined dialogically, in interaction with rather than in isolation from the particular needy subject(s). ${ }^{160}$ Participatory parity is precisely the standard that provides the justificatory force for the theory as well as drives it. If existing patterns of cultural values misrecognise some social groups and consequently impede participatory parity, then participatory parity serves, in Fraser's words, the 'idiom of public contestation and deliberation about questions of justice' ${ }^{161}$ It is not populism, authoritarianism or paternalism that delivers universal justice needed for human flourishing, but democratic deliberation in which there is participatory parity.

157 Ibid., at $113-14$.

158 Ibid., at 113.

159 Fraser and Honneth, Redistribution or Recognition?, supra note 10, pp. 1-48.

160 Ibid., pp. 42-8.

161 Ibid., p. 43. 
In this way, the theory of recognition sets out to interact with the human dignity, equality and freedom of all affected parties as a prerequisite to repairing injury.

The import of Fraser's recognition theory is that abortion laws ought to aspire towards standards of not just accountability and openness, but even more pertinently, responsiveness. In African settings abortion laws ought to recognise that on account of endemic levels of poverty and illiteracy, in general, African women have a greater material need for transparency than their European counterparts, for example. Therefore, the duty of transparency in abortion laws in the African region ought to be even more exacting if it is to be responsive and enabling. Rather than merely draft laws in a clear manner and provide ancillary guidance and administrative procedures for the effective realisation of any abortion rights that are guaranteed, in the African region, it would also be commensurate with the needs of African women to require the State to take positive steps to raise awareness about unsafe abortion and the availability of laws and services for lawful abortions. Such steps should be regarded as the 'institutional prerequisites for participatory parity' in African abortion regimes.

\section{B. Transparency and capabilities}

It is also possible to posit the imperative of transparency in terms of the 'capabilities approach' that has been developed by Amartya Sen ${ }^{162}$ and Martha Nussbaum. ${ }^{163}$ Sen pioneered the capabilities approach as a leading alternative standard to utilitarian approaches that had traditionally been used by economists and political scientists to measure and compare the welfare of the people in individual countries. Instead of using a utilitarian calculus to measure the total or aggregate sum of happiness, Sen advanced the capabilities approach as a fairer approach for making comparisons about the quality of life. Unlike a utilitarian calculus, which overlooks the predicament and barriers faced by social groups and individuals in a socio-economically stratified society, the capabilities approach puts both equity and freedom at its centre. The capabilities approach does not ask about people's satisfactions in the abstract or merely the quantity of resources at their disposal, but rather what they are actually able to do if they have the requisite material capacity. ${ }^{164}$

The capabilities approach serves the cause of human rights and substantive equality by being acutely responsive to the freedom needs of the individual in question and not an abstract individual or society. In this way, the capabilities approach has, inter alia, sought to close what Sen has critiqued as a gap between 'freedoms' and 'means to freedoms' in Rawls' theory of justice. ${ }^{165}$ This is

162 Sen, Development as Freedom, supra note 11; Sen, 'Elements of a Theory of Human Rights', supra note 11; Sen, 'Gender Inequality and Theories of Justice', supra note 11.

163 Nussbaum, Women and Human Development, supra note 12; Nussbaum, 'Human Capabilities, Female Human Beings', supra note 12, pp. 62-104.

164 Nussbaum, Women and Human Development, ibid., pp. 12-13.

165 Sen, 'Gender Inequality and Theories of Justice', supra note 11, at 263-6; Nussbaum, Women and Human Development, supra note 12, pp. 65-70. 
captured clearly in the following statement, where Sen is explaining what the capabilities approach means and alluding to its juxtaposition with, and, indeed, advantage over, Rawls' theory of justice:

If the object is to concentrate on the individual's real opportunity (as Rawls explicitly recommends), then account would have to be taken not only of the primary goods the persons respectively hold, but also of the relevant personal characteristics that govern the conversion of primary goods into the person's ability to promote her ends. For example, a person who is disabled may have a larger basket of primary goods and yet have less chance to lead a normal life. Similarly, an older person or a person more prone to illness, can be more disadvantaged in a generally accepted sense even with a larger bundle of primary goods. ${ }^{166}$

The capabilities approach represents the substantive freedom of an individual to achieve a certain functioning or lifestyle that the individual has reason to value. There are two types of functionings or thresholds that the capabilities approach can measure: the realised or actual functionings, that is, what a person is actually able to do, and capability functioning, that is, the set of real opportunities open to the individual; ${ }^{167}$ however, proponents of the capabilities approach frequently conflate the two. For the purposes of the arguments in this article, the distinction is not important. What is crucial is that the capabilities approach measures what a particular person is substantively or actually free to do, taking into account their personal circumstances and socio-economic context.

Martha Nussbaum's main contribution to the capabilities discourse has been to exigently connect the capabilities approach with gender equality and human rights as part of a woman-centred universal equality discourse. ${ }^{168}$ Nussbaum has used the capabilities approach as a category of gender analysis for the achievement of de jure rather than de facto equality of women in a universe where, in many spheres, women are second-class citizens lacking in 'capabilities' precisely because unequal socio-economic circumstances, not least structural inequality, give women 'who have rarely been kings, or nobles, or rich but frequently poor, sick and dead', unequal human capabilities. ${ }^{169}$ Nussbaum's point of departure is that, even allowing for different conceptions of a good life, as a matter of human dignity, there are a set of capabilities that all human beings require in order to flourish. And while the precise threshold of each capability is something that can be dialogically worked out among citizens, what is crucial is that capabilities are a normative moral claim on the State, and furthermore, that the

166 Sen, Development as Freedom, supra note 11, p. 74.

167 Nussbaum, Women and Human Development, supra note 12, pp. 70-86; Nussbaum, 'Human Capabilities, Female Human Beings', supra note 12, pp. 81-6.

168 Nussbaum, Women and Human Development, ibid., p. 6; Nussbaum, 'Human Capabilities, Female Human Beings', ibid., p. 63.

169 Nussbaum, 'Human Capabilities, Female Human Beings', ibid., p. 62; Nussbaum, Women and Human Development, ibid., p. 1. 
capabilities threshold is incompatible with a systemic patterns of inequality. ${ }^{170}$ As a matter of redistributive justice, the State must take positive steps to redress unequal capabilities by creating the material conditions for the realisation of the capabilities to meet a certain minimum threshold. ${ }^{171}$

Nussbaum (though not Sen) has come up with a list of capabilities that are taken as central capabilities to mark those capabilities that are universal and amenable to cross-cultural consensus. Central capabilities include being able to live and not die prematurely, being able to preserve health, including reproductive health, and being able to protect bodily integrity. ${ }^{172}$ If it can be accepted that being able to meaningfully exercise the choice to live, to be healthy and to have sovereignty over reproductive choices is a central capability, ${ }^{173}$ it is possible to argue that in social and political environments where abortion is permitted under the law, but is generally assumed by women and healthcare providers to be illegal because of lack of reliable information about the legality of abortion, then any abortion rights that are conferred are merely rhetorical freedoms that are lacking in a 'threshold condition' ${ }^{174}$ of special importance. Such freedoms are meaningless as they cannot achieve a minimum threshold of capability and material equality. Women in the African region generally lack reliable information about the option of safe, legal abortion. The phenomenon of unsafe abortion that is linked to restrictive laws, or laws that are applied restrictively or perceptions thereof is sufficient evidence of lack of capabilities. The existence of adequate knowledge to choose safe abortion over unsafe abortion and availability of accessible procedures for vindicating abortion rights can, using the capabilities approach, be treated as "combined capabilities' ${ }^{175}$ whose realisation is tethered to the injustice of gender inequality and the imperative of achieving substantive equality. In this sense, lack of transparency constitutes a violation of a capability opportunity when women are forced to choose unsafe, illegal abortion, partly because abortion law has not been effectively implemented.

\section{CONCLUSION}

Laws that permit abortion should not remain opaque and/or unknown to women who need abortion services or to providers who are, otherwise, willing to provide abortion services. Transparency is a juridical modality for shifting the focus of abortion law reform from preoccupation with only substantive reform to seeing reforms as also aimed at securing procedural fairness and equality under the law. By putting a spotlight on consensus about procedural fairness, states can be

170 Nussbaum, 'Human Capabilities, Female Human Beings', ibid., p. 86.

171 Ibid., p. 97.

172 Ibid., pp. 72-86.

173 Nussbaum, Women and Human Development, supra note 12, p. 78; Nussbaum, 'Human Capabilities, Female Human Beings', ibid., p. 83.

174 Sen, 'Elements of a Theory of Human Rights', supra note 11, at 329; Nussbaum, Women and Human Development, ibid.; Nussbaum, 'Human Capabilities, Female Human Beings', ibid., pp. 81-6.

175 Nussbaum, Women and Human Development, ibid., p. 98. 
held accountable so that abortion rights that states, themselves, have chosen to guarantee in their laws are not illusory. Transparency seeks to render the right to terminate pregnancy real or tangible in practice. It serves to recognise women as women and to accord them capabilities for realising legal rights, thus alleviating the disabilities that are frequently experienced by women who seek to exercise their entitlements under the law.

In the final analysis, it is argued that transparency can be understood as a duty upon the State to adequately translate any rights that are conferred on individuals into something that is concrete and claimable. In this sense, regardless of its appositeness to the implementation of abortion rights, transparency is not a state duty that is peculiar to abortion. Rather, it is a duty that ought to be an incident of duties correlative to individual rights in general in a constitutional democracy where citizens would not otherwise be able to easily or effectively realise their rights unless the substantive entitlements have been articulated in a manner that is reasonably clear and there are accessible enforcement mechanisms. ${ }^{176}$ Furthermore, citizens must be aware of such entitlements and enforcement mechanisms.

Otherwise, this article concedes that there are limits to transparency. Even more importantly, it is conceded that transparency in abortion law is not an unqualified good. It can also be a double-edged sword to the extent that transparency can enable as well as disable. When dealing with a contested need such as abortion, transparency has the capacity to straightjacket abortion law so as to preclude the flexibility that is needed in law as a dynamic and living entity so that it is responsive, not just to current abortion needs, but also to future needs and developments, including changing values and technological developments. Furthermore, transparency cannot, in any event, succeed in totally avoiding the complexities that are inherent in any law that regulates as contested a need as abortion. Trying to render foetal jurisprudence transparent, especially, is apt to be fraught with the dangers of paradoxically rendering even more complex an area of great complexity or avoiding and, worse still, evading complexity. ${ }^{177}$ The point, though, is that the complexity of abortion laws should not be used speciously to frustrate given rights.

176 M. Pieterse, 'Legislative and Executive Translations of the Rights to Have Access to Health Care Services', 14 Law, Democracy \& Development (2010): 1-25; L. Williams, 'Issues and Challenges in Addressing Poverty and Legal Rights: A Comparative United States/South African Analysis', 21 South African Journal on Human Rights (2005): 436-72, at 439.

177 H. Irving, Gender and the Constitution, Cambridge University Press (2008), pp. $206-7$. 